\title{
ON-FARM EVALUATION OF PRODUCTION POTENTIAL AND ECONOMICS OF FOUR CROPS BASED CROPPING PATTERN
}

\author{
S. K. Bhowal ${ }^{1}$, M. H. Hossain ${ }^{2}$ and M. M. Bashir ${ }^{3}$ \\ ${ }^{1}$ Scientific Officer, ${ }^{2}$ Principal Scientific Officer, ${ }^{3}$ Senior Scientific Officer, \\ OFRD, BARI, Cumilla, Bangladesh \\ Correspondng E-mail: shamal.bau@gmail.com
}

(Received: 11 April 2021, Accepted: 21 April 2021)

Keywords: On-farm assessment, four crops, cropping pattern, cropping intensity, system productivity

\begin{abstract}
A field experiment was conducted at multi-location testing (MLT) site, Barura under On-Farm Research Division (OFRD), Bangladesh Agricultural Research Institute, Cumilla during 2014-16 to determine the productivity and profitability of cropping patterns, viz. Boro (var. BRRI dhan28)-T.Aus (var. BRRI dhan48)- T. Aman (var. BRRI dhan49)-Fallow (existing cropping pattern) and Boro (var. BRRI dhan28)-T. Aus (var. BRRI dhan48)-T. Aman (var. Binadhan-11)-Mustard (var. BARI Sarisha14) as improved cropping pattern. The results showed that improved cropping pattern provided higher amount of grain and by-product yield. The highest mean REY (18.08 t ha-1), PE (54.61 kg ha- ${ }^{-1}$ day $\left.^{-1}\right)$, LUE (90.68 \%) and SYI (77.12\%) was obtained from improved cropping pattern Boro-T.Aus-T. Aman-Mustard and the lowest (14.30 $\mathrm{t} \mathrm{ha}^{-1}$ in 2014-15 and $13.98 \mathrm{t} \mathrm{ha}^{-1}$ in 2015-16) from farmers existing cropping pattern. The highest gross return (Tk. 274800 ha $^{-1}$ in 2014-15 and Tk. 276600 ha $^{-1}$ in 2015-16), gross margin (Tk. 113950 ha $^{-1}$ in 2014-15 and Tk. $106750 \mathrm{ha}^{-1}$ in 2015-16) and BCR (1.70 in 2014-15 and 1.66 in 2015-16) were obtained from improved four crops based cropping pattern (Boro-T. Aus-T. AmanMustard). Two years results showed that four crops could be grown one after another in a sequence in the farmers field of Cumilla region for achieving higher system productivity and economic return.
\end{abstract}

\section{Introduction}

Bangladesh is a densely populated country with lower per capita arable land (12 decimal head $\left.{ }^{-1}\right)$ usage. The annual loss of agricultural land is about $0.73 \%$ per annum mainly due to construction of houses, roads and industrial infrastructure (BBS, 2019). Thus increase of cropping intensity in rice based cropping system is becoming important for food security and poverty alleviation. A vast area remains fallow after the harvest of $\mathrm{T}$. Aman rice in Cumilla and Chandpur district of Bangladesh. In near future, the main challenge is to increase $50 \%$ yield per unit land by manipulating limited resources. In order to produce more food within a limited area, the most important options are to increase the cropping intensity and to increase the production efficiency of the individual crop by using optimum management practices (Mondal et al., 2015). Recently with the development of short duration varieties of rice, mustard, potato, pulse and jute, opportunities have been created to accommodate four crops in same piece of land in a year (Azad et al., 2020).

Cumilla region is highly diversified in respect to topography, agro-ecology, land-use pattern and cropping system. Barura upazila occupies the highest cropping intensity (CI) of $292 \%$ followed 
by Debidwar (265\%) and Chandina (250\%) under Cumilla district which are much more higher than the national average rendering those upazilas as the most intensive cropping area of the country (Saha et al., 2017). Cumilla is the highest rice growing district in Bangladesh where Boro-T. Aus-T. Aman-Fallow is one of the major cropping patterns in the district covering of an areas of 47,350 ha (DAE, 2019). Rice is a promising cash crop in this region. By changing the variety of $\mathrm{T}$. Aman, a short duration mustard variety can be easily fitted in Boro-T. Aus-T. Aman-Fallow cropping pattern. Thus it is expected that inclusion of mustard in Boro-T. Aus-T. Aman-Fallow cropping pattern would increase cropping intensity and productivity in Cumilla region. Further, adoption of this alternate cropping pattern Boro-T. Aus-T. Aman-Mustard can generate employment and the additional income for the rural poor of the region (Hossain et al., 2017). To utilize the fallow land and to increase mustard production, it may be introduced in the fallow period before boro cultivation in the existing Boro-T. Aus-T. Aman rice -Fallow cropping pattern. Potential adoption of this improved cropping pattern intensifying mustard in Boro-T. Aus-T. Aman-Fallow cropping system can generate employment and the addition of income for the rural poor and save foreign exchange for edible oil import. Considering the above issues, the present study was undertaken to ascertain feasibility of growing four crops in sequence for increasing cropping intensity, productivity and income of farm families of Cumilla region of Bangladesh.

\section{Materials and Methods}

The experiment was conducted at Folkamuri, Barura under Cumilla district during 2014-15 and 2015-16. The crop field was sandy loam soil and it belongs to Chandina soil series under the Agro Ecological Zone (AEZ)-19. Initial and final chemical properties of experimental soils are presented in the Table 1. The trial was conducted to derive the economic consequences of four cropping patterns viz. Boro-T. Aus-T. Aman-Mustard (improved cropping pattern) and Boro- T. Aus- T. Aman-Fallow (existing cropping pattern). The experiment was laid out in a Randomized Complete Block design with four dispersed replications. Two plots of 250 decimal were selected. One for the improved pattern and the others for farmers pattern. Boro rice variety BRRI dhan28, T. Aus rice variety BRRI dhan 48 and T. Aman rice variety Binadhan-16 were used in both existing and improved cropping pattern. In the improved cropping pattern, Mustard variety BARI Sarisha-14 was introduced against fallow period.

The experimental soil was sandy loam with low organic matter content $(2.26 \%)$ and soil $\mathrm{pH}$ was ranged 5.40-5.47 acidic in nature. The status of N, P, K, B and $\mathrm{Zn}$ was low, optimum, low, very high and low, respectively (Table 1). The experimental design was a randomized complete block with six dispersed replications.

Table 1. Initial and final soil properties of the farmer's field at Barura, Cumilla during 2014-15 and 2015-16

\begin{tabular}{|c|c|c|c|c|c|c|c|c|}
\hline \multirow{2}{*}{$\begin{array}{c}\text { Soil } \\
\text { Properties }\end{array}$} & \multirow{2}{*}{$\begin{array}{l}\text { Land } \\
\text { type }\end{array}$} & \multirow[t]{2}{*}{$\mathrm{pH}$} & \multirow{2}{*}{$\begin{array}{c}\text { Organic } \\
\text { matter } \\
(\%)\end{array}$} & \multirow{2}{*}{$\begin{array}{c}\mathrm{K} \\
\text { meq100 } \mathrm{ml}^{-1} \text { soil }\end{array}$} & \multirow{2}{*}{$\begin{array}{l}\text { Total } \\
\mathrm{N}(\%)\end{array}$} & \multirow{2}{*}{\multicolumn{3}{|c|}{$\frac{\mathrm{Zn}}{\mathrm{gml}^{-1}}$}} \\
\hline & & & & & & & & \\
\hline Initial & MHL & 5.47 & 2.26 & 0.14 & 0.16 & 24.5 & 2.91 & 0.24 \\
\hline Final & MHL & 5.40 & 2.30 & 0.16 & 0.13 & 18.75 & 2.95 & 0.62 \\
\hline Critical Level & - & - & - & 0.12 & 0.12 & 8. 0 & 0.6 & 0.20 \\
\hline
\end{tabular}

Analyzed by: Regional Soil Resource Development Institute Laboratory, Cumilla; MHL: Medium High Land 
The agronomic practices used for crop production under existing and improved cropping pattern are presented in Table 2. Land use efficiency, production efficiency, rice equivalent yield and sustainable yield index of cropping patterns were calculated as follows:

Table 2. Agronomic practices employed in existing and improved cropping patterns at MLT site Amratoli, Barura under Cumilla district (average of 2014-15 and 2015 -16)

\begin{tabular}{|c|c|c|c|c|c|c|c|c|}
\hline Parameters & Existi & ng Cropping & pattern (ECP) & & Imprc & ved Cropping & g Pattern (l & ICP) \\
\hline Crop & Boro rice & T. Aus rice & $\begin{array}{l}\text { T. Aman } \\
\text { rice }\end{array}$ & Fallow & Boro rice & T. Aus rice & $\begin{array}{l}\text { T. Aman } \\
\text { rice }\end{array}$ & Mustard \\
\hline Variety & $\begin{array}{c}\text { BRRI } \\
\text { dhan28 }\end{array}$ & $\begin{array}{c}\text { BRRI } \\
\text { dhan48 }\end{array}$ & $\begin{array}{c}\text { BRRI } \\
\text { dhan49 }\end{array}$ & - & $\begin{array}{c}\text { BRRI } \\
\text { dhan28 }\end{array}$ & BRRI dhan 48 & $\begin{array}{c}\text { Bina } \\
\text { dhan-11 }\end{array}$ & $\begin{array}{c}\text { BARISarish } \\
\text { a-14 }\end{array}$ \\
\hline $\begin{array}{l}\text { Date of } \\
\text { transplanting } \\
\text { / sowing }\end{array}$ & $\begin{array}{c}26-28 \\
\text { January }\end{array}$ & 10-13 May & $\begin{array}{l}\text { 15-18 } \\
\text { August }\end{array}$ & - & $\begin{array}{l}\text { Seed bed } \\
\text { 30Dec. } \\
\text { Transplanted } \\
02-05 \text { Feb }\end{array}$ & $\begin{array}{l}\text { Seed bed, } 16 \\
\text { April } \\
\text { Transplanted } \\
\text { 07-08 May }\end{array}$ & $\begin{array}{c}\text { Seed } \\
\text { bed } 16 \\
\text { July } \\
\text { Trans. } \\
13-15\end{array}$ & 14-15 Nov. \\
\hline $\begin{array}{l}\text { Seed rate } \\
\left(\mathrm{Kg} \mathrm{ha}^{-1}\right)\end{array}$ & 40 & 40 & 40 & - & 35 & 35 & $\begin{array}{l}\text { Aug, } \\
35\end{array}$ & 07 \\
\hline $\begin{array}{l}\text { Seedling } \\
\text { age/days }\end{array}$ & 35 & 30 & 30 & - & 32 & 21 & 28 & - \\
\hline $\begin{array}{l}\text { Planting } \\
\text { method }\end{array}$ & Line & Line & Line & & Line & Line & Line & Broadcast \\
\hline Spacing & $\begin{array}{c}20 \\
\mathrm{~cm} \times 15 \mathrm{~cm}\end{array}$ & $\begin{array}{c}15 \\
\mathrm{~cm} \times 15 \mathrm{~cm}\end{array}$ & $\begin{array}{l}25 \mathrm{~cm} \\
\times 15 \mathrm{~cm}\end{array}$ & - & $\begin{array}{r}20 \mathrm{~cm} \\
\times 15 \mathrm{~cm}\end{array}$ & $\begin{array}{l}15 \mathrm{~cm} \\
\times 15 \mathrm{~cm}\end{array}$ & $\begin{array}{c}20 \\
\mathrm{~cm} \times 15 \\
\mathrm{~cm}\end{array}$ & Broadcast \\
\hline $\begin{array}{l}\text { Fertilizer dose } \\
\text { (NPKSZnB, } \\
\mathrm{Kg} \mathrm{ha}^{-1} \text { ) }\end{array}$ & $\begin{array}{c}92-24-24-8- \\
0.5-0\end{array}$ & $\begin{array}{l}60-20-35- \\
9.0-1.0-0\end{array}$ & $\begin{array}{c}78-24-60-8- \\
0.5-0\end{array}$ & - & $\begin{array}{c}120-24-12- \\
6.5-2.8-0\end{array}$ & $\begin{array}{c}69.1-15- \\
37.5-9.6- \\
1.8-0\end{array}$ & $\begin{array}{c}82.9-24- \\
35-10.4- \\
6.11-0\end{array}$ & $\begin{array}{c}115-34-20- \\
28.8-2.51- \\
1.70\end{array}$ \\
\hline $\begin{array}{l}\text { Fertilizer } \\
\text { application } \\
\text { method }\end{array}$ & $\begin{array}{l}\text { All PKS used } \\
\text { as basal } \\
\text { during final } \\
\text { land } \\
\text { preparation. } \\
\mathrm{N} \text { used in } 2 \\
\text { equal splits }\end{array}$ & $\begin{array}{l}\text { All PKS used } \\
\text { as basal } \\
\text { during final } \\
\text { land } \\
\text { preparation. } \\
\mathrm{N} \text { used in } 2 \\
\text { equal splits }\end{array}$ & $\begin{array}{l}\text { All PKS used } \\
\text { as basal } \\
\text { during final } \\
\text { land } \\
\text { preparation. } \\
\mathrm{N} \text { used in } 2 \\
\text { equal splits }\end{array}$ & - & $\begin{array}{l}\text { All PKSZn } \\
\text { and } 1 / 3 \mathrm{~N} \\
\text { used as basal } \\
\text { and rest } 2 / 3 \\
\mathrm{~N} \text { used in } 3 \\
\text { equal splits, } \\
21 \text { DAT, } \\
35 \text { DAT and } \\
\text { at } 45 \text { DAT. }\end{array}$ & $\begin{array}{l}\text { All PKSZn } \\
\text { used as basal } \\
\text { and N used in } \\
2 \text { equal splits, } \\
15 \text { DAT \& } \\
\text { at } 30-35 \\
\text { DAT. }\end{array}$ & $\begin{array}{l}\text { All } \\
\text { PKSZn } \\
\text { used as } \\
\text { basal } \\
\text { and N } \\
\text { used in } 3 \\
\text { equal } \\
\text { splits, } 7 \\
\text { DAT, } \\
\text { 22 DAT } \\
\text { and 5-7 } \\
\text { days } \\
\text { before } \\
\text { panicle } \\
\text { initiation } \\
\text { stage. }\end{array}$ & $\begin{array}{l}\text { All PKSZn } \\
\text { and half } \mathrm{N} \\
\text { used as } \\
\text { basal and } \\
\text { rest } \mathrm{N} \text { used } \\
\text { in } 20-25 \\
\text { days after } \\
\text { seed } \\
\text { germination } \\
\text { at prior to } \\
\text { flowering } \\
\text { stage. }\end{array}$ \\
\hline $\begin{array}{l}\text { Irrigation/ } \\
\text { rainfed }\end{array}$ & Irrigated & Rainfed & Rainfed & - & Irrigated & Irrigated & Irrigated & Rainfed \\
\hline $\begin{array}{l}\text { Insect-pest } \\
\text { control }\end{array}$ & Chemical & Chemical & Chemical & - & IPM & IPM & IPM & IPM \\
\hline $\begin{array}{l}\text { Harvesting } \\
\text { date }\end{array}$ & 26-29 April & 25-27 July & 02-05 Dec. & - & 23-25 April & 03-05 Aug & $\begin{array}{c}09-11 \\
\text { Nov. }\end{array}$ & 01-03 Feb. \\
\hline $\begin{array}{l}\text { Field duration } \\
\text { (days) }\end{array}$ & 90-92 & $75-78$ & $107-110$ & - & $80-82$ & $87-89$ & $87-90$ & $77-78$ \\
\hline
\end{tabular}

Land use efficiency: Land use efficiency is worked out by taking total duration of individual crop in a sequence divided by 365 days (Tomer and Tiwari, 1990). It is calculated by following formula. 
Land use efficiency $=\frac{\mathrm{d}_{1}+\mathrm{d}_{2}+\mathrm{d}_{3}}{365} 100$

Where $d_{1}, d_{2}$ and $d_{3}$ the duration of first, second and third crops of the pattern.

Production efficiency: Production efficiency values were calculated by total production in a cropping sequence divided by total duration of crops in that sequence (Tomer and Tiwari, 1990).

Production efficiency $=\frac{Y_{1}+Y_{2}+Y_{3} K g \cdot h^{-1} \text { day }^{-1}}{d_{1}+d_{2}+d_{3}}$

Where, $Y_{1}=$ Yield of first crop and $d_{1}=$ Duration of first crop of the pattern

$\mathrm{Y}_{2}=$ Yield of second crop and $\mathrm{d}_{2}=$ Duration of second crop of the pattern

$\mathrm{Y}_{3}=$ Yield of third crop and $\mathrm{d}_{3}=$ Duration of third crop of the pattern

Sustainable yield index: Sustainable yield index (SYI) was computed following the formula of Krishna and Reddy (1997) as given below.

Sustainable yield index $(\mathrm{SYI})=\frac{\mathrm{Y}_{\text {mean }}-\mathrm{SD}}{\mathrm{Y}_{\text {mean }}} 100$

Where, $\mathrm{Y}_{\text {mean }}$ : Estimated mean yield of a practice over years, SD: Estimated standard deviation and $Y_{\max }$ : Observed maximum yield in the experiment over the years.

Rice equivalent yield (REY): For comparison between crop sequences, the yield of all crops was converted into rice equivalent on the basis of prevailing market price of individual crop (Verma and Modgal, 1983).

Rice equivalent yield $\left(t \mathrm{th}^{-1}\right)=$

Yield of individual crop $\times$ Market price of that crop

The economic indices like gross and net returns and benefit cost ratio were also calculated on the basis of prevailing market price of the produces and different operations performed and materials used for raising crops.

Benefit Cost Ratio (BCR) was calculated by the following formula:

Benefit Cost Ratio $(\mathrm{BCR})=$

Gross return $\left(T k . h^{-1}\right)$

Total cost of cultivation (Tk. ha $\left.{ }^{-1}\right)$

Rice plant was harvested at $12-20 \mathrm{~cm}$ height from soil surface and remaining parts of the plant was incorporated with soil. Grain and by- product yields were collected from harvested plants. The data were recorded on different parameters and presented in the table.

\section{Results and Discussion}

\section{Grain and by-product yield of Crops in Cropping Patterns}

Yield of different crops in improved and existing cropping patterns are presented in Table 3. Improved pattern required 228-332 days against 285-288 days due to inclusion of mustard (var. 
BARI Sarisha-14) instead of fallow period in the pattern. Field duration of T. Aman rice (var. Binadhan-11) in the improved cropping pattern was shorter due to change of variety. The yield of $\mathrm{T}$. Aman rice was also lower in the improved pattern than the existing cropping pattern. The yield of Boro rice and $\mathrm{T}$. Aus rice was higher in the improved pattern than the existing cropping in both the years except Boro rice in 2014-15. Improved cropping pattern showed higher grain yield of Boro rice by $6.20 \mathrm{t} \mathrm{ha}^{-1}$ in 2014-15 and 6.34 $\mathrm{t} \mathrm{ha}^{-1}$ in 2015-16 and T. Aman rice by $4.45 \mathrm{t} \mathrm{ha}^{-1}$ in $2014-15$ and $4.35 \mathrm{t} \mathrm{ha}^{-1}$ in $2015-16$ over existing pattern except 2015-16 in T. Aman rice. Higher yield of rice possibly due to improved production technologies. Similar results were obtained by Mandal et al. (2015), Nazrul et al. (2017), Khan (2018). The improved cropping pattern produced higher amount of total by-product yield $\left(18.74 \mathrm{t} \mathrm{ha}^{-1}\right)$ than the farmers' existing pattern (15.49 $\mathrm{t} \mathrm{ha}^{-1}$ ). The by-product yield of improved pattern was higher due to change of variety with improved technologies for the component crops. Similar results were also documented by Hossain et al. (2014) and Hossain et al. (2017). Mustard (var. BARI Sarisha14 ) in improved pattern produced valuable by-products in both the years. So, farmers are able to use the by-product of rice and mustard in domestic purpose and also sale in the local market with high price.

Table 3. Productivity of existing and improved cropping patterns at MLT site Amratoli, Barura under Cumilla district during 2014-15 and 2015 -16

\begin{tabular}{|c|c|c|c|c|c|c|c|c|c|}
\hline \multirow[t]{2}{*}{ Productivity } & \multirow[t]{2}{*}{ Years } & \multicolumn{4}{|c|}{ ECP (Existing Cropping Pattern) } & \multicolumn{4}{|c|}{ ICP (Improved Cropping Pattern) } \\
\hline & & $\begin{array}{l}\text { Boro } \\
\text { rice }\end{array}$ & $\begin{array}{l}\mathrm{T} . \\
\text { Aus } \\
\text { rice }\end{array}$ & $\begin{array}{l}\text { T. Aman } \\
\text { rice }\end{array}$ & Fallow & $\begin{array}{l}\text { Boro } \\
\text { rice }\end{array}$ & $\begin{array}{l}\text { T. Aus } \\
\text { rice }\end{array}$ & $\begin{array}{l}\text { T. Aman } \\
\text { rice }\end{array}$ & Mustard \\
\hline \multirow[t]{3}{*}{$\begin{array}{l}\text { Grain yield } \\
\left(\mathrm{t} \mathrm{ha}^{-1}\right)\end{array}$} & $\begin{array}{c}2014- \\
15\end{array}$ & 6.39 & 3.48 & 4.43 & - & 6.20 & 4.29 & 4.45 & 1.69 \\
\hline & $\begin{array}{c}2015- \\
16\end{array}$ & 5.89 & 3.32 & 4.77 & - & 6.34 & 4.21 & 4.35 & 1.47 \\
\hline & Mean & 6.14 & 3.40 & 4.60 & - & 6.27 & 4.25 & 4.40 & 1.58 \\
\hline \multirow[t]{3}{*}{$\begin{array}{l}\text { By product } \\
\text { yield }\left(\mathrm{t} \mathrm{ha}^{-1}\right)\end{array}$} & $\begin{array}{c}2014- \\
15\end{array}$ & 6.46 & 4.52 & 4.68 & - & 6.23 & 4.49 & 4.90 & 3.16 \\
\hline & $\begin{array}{c}2015- \\
16\end{array}$ & 6.32 & 4.42 & 4.58 & - & 6.19 & 4.63 & 4.76 & 3.12 \\
\hline & Mean & 6.39 & 4.47 & 4.63 & - & 6.21 & 4.56 & 4.83 & 3.14 \\
\hline
\end{tabular}

\section{System Productivity}

Rice equivalent yield (REY) was different under different cropping sequences. The highest REY (18.08 $\mathrm{t} \mathrm{ha}^{-1}$ ) was recorded from the improved cropping pattern Boro-T. Aus-T.Aman-Mustard and the lowest (14.14 t ha-1) from the existing cropping pattern i.e. Boro- T. Aus- T. Aman (Table 4). Rice equivalent yield in the improved cropping pattern was higher compared to existing cropping pattern due to the inclusion of mustard with management practices. Improved cropping pattern increased REY about $27.86 \%$ compared to farmers existing cropping pattern. Inclusion of high yielding new variety (Binadhan-11) and improved management practices in the improved pattern increased the T. Aman rice equivalent yield. Lower rice equivalent yield was obtained in the farmer's pattern possibly due to traditional management practices. Similar trend was noted by Naher et al. (2016). Maximum production efficiency $\left(54.61 \mathrm{~kg} \mathrm{ha}^{-1} \mathrm{day}^{-1}\right.$ ) was obtained from improved cropping pattern in both the years (Table 4). The higher production efficiency of improved cropping pattern might be due to improved management practices. The lowest production efficiency (51.98 kg ha- day ${ }^{-1}$ ) was observed in farmers' existing pattern 
where improved management practices easily. Similar trends were noted by Nazrul et al. (2013) and Khan et al. (2005). The average land-use efficiency indicated that improved cropping pattern used the land for $91.52 \%$ in 2014-15 and $89.84 \%$ in 2015-16, period of the years, whereas farmer's existing cropping pattern used the land for $73.47 \%$ in $2014-15$ and $75.57 \%$ in 2015-16, period of the years (Table 4). The land use efficiency was higher in improved cropping pattern because of the cultivation of mustard as fourth crop in a fallow land and longest field duration (331 days). The farmers existing pattern occupied the field for 272 days of the year. The values of sustainable yield index (SYI) as a measure of sustainability of the system which was high in the improved cropping system over farmer's practice (Table 4). ICP recorded the highest SYI of 78.28 \% in 2014-15 and 75.96 \% in 2015-16 followed by ECP $(70.23 \%$ in 2014-15 and 68.15\% in 2015-16). It indicates that cropping system involving mustard in fallow period i.e four crop based improved cropping pattern recorded higher SYI compared to three rice crop based farmers existing crop sequence. So, improved pattern is therefore, more stable than farmer's pattern. Short duration mustard variety BARI Sarisha-14 could provide special advantage regarding utilization of fallow period in cropping sequence as well as increased production of mustard. The results are in agreement with the findings of Ram et al. (2012).

Table 4. Rice equivalent yield, production efficiency, land use efficiency and sustainable yield index of existing and improved cropping patterns during 2014-15 and 2015 -16

\begin{tabular}{|c|c|c|c|c|c|}
\hline $\begin{array}{l}\text { Cropping } \\
\text { patterns }\end{array}$ & Years & $\begin{array}{c}\text { Rice equivalent } \\
\text { yield } \\
\text { (t ha-1) }\end{array}$ & $\begin{array}{c}\text { Production } \\
\text { efficiency } \\
\left(\mathrm{kg} \mathrm{ha}^{-1} \text { day }^{-1}\right)\end{array}$ & $\begin{array}{l}\text { Land use } \\
\text { efficiency } \\
\text { (\%) }\end{array}$ & $\begin{array}{l}\text { Sustainable yield } \\
\text { index } \\
(\%)\end{array}$ \\
\hline \multirow[t]{2}{*}{ ECP } & 2014-15 & 14.30 & 52.57 & 73.47 & 70.23 \\
\hline & $2015-16$ & 13.98 & 51.39 & 75.57 & 68.15 \\
\hline \multicolumn{2}{|c|}{ Mean } & 14.14 & 51.98 & 74.52 & 69.19 \\
\hline \multirow[t]{2}{*}{ ICP } & 2014-15 & 18.32 & 55.34 & 91.52 & 78.28 \\
\hline & $2015-16$ & 17.84 & 53.89 & 89.84 & 75.96 \\
\hline \multicolumn{2}{|c|}{ Mean } & 18.08 & 54.61 & 90.68 & 77.12 \\
\hline
\end{tabular}

Market price of Mustard @ $30 \mathrm{Tk} \mathrm{kg}^{-1}$, Rice@ $15 \mathrm{Tk} \mathrm{kg}^{-1}$, Urea @ 16, TSP @ 24, MP @15,Zypsum @10, Zinc Sulphate @ 120 and Boric acid@ $150 \mathrm{Tk} \mathrm{kg}^{-1}$, ECP = Existing cropping pattern, ICP = Improved Cropping Pattern

\section{Economics}

Economic analysis was done on the basis of prevailing market price of the commodities. The gross return was different for different cropping patterns. The highest gross return (Tk. 274800 ha-1) in 2014-15 and (Tk. 276600 ha $^{-1}$ ) in 2015-16 and gross margin (Tk. 113950 ha $^{-1}$ ) in 2014-15 and (Tk. 106750 ha $^{-1}$ ) in 2015-16 were obtained in improved Boro-T.Aus-T. AmanMustard cropping pattern and the lowest gross return (Tk. $214500 \mathrm{ha}^{-1}$ ) in 2014-15 and (Tk. $209700 \mathrm{ha}^{-1}$ ) in 2015-16 and gross margin (Tk. $76950 \mathrm{ha}^{-1}$ ) in 2014-15 and (Tk. $\left.72150 \mathrm{ha}^{-1}\right)$ in 2015-16 were found in existing cropping pattern (Table 5). The highest total cultivation cost (Tk. $160850 \mathrm{ha}^{-1}$ in 2014-15 and 2015-16) was recorded from cropping sequence Boro-T. Aus-T. Aman-Mustard, due to the inclusion of mustard in improved cropping pattern and the lowest (Tk. $137550 \mathrm{ha}^{-1}$ in 2014-15 and 2015-16) from the existing cropping sequence BoroT. Aus- T. Aman-Fallow. The highest (1.70) BCR in 2014-15 and (1.66) BCR in 2015-16 was recorded in improved Boro-T. Aus-T. Aman-Mustard cropping pattern compared to the farmers existing cropping pattern Boro- T. Aus- T. Aman-Fallow (1.55) in 2014-15 and in (1.52) in (2015-16). Others (Mondal et al., 2014, Khan et al., 2020 and Bhowal et al., 2019) agreed that 
the four crop based cropping pattern would play a vital role to ensure food security of the country in upcoming days.

Table 5. Cost and return analysis of existing and improved cropping pattern at MLT site Amratoli, Barura under Cumilla district during 2014-15 and 2015-16

\begin{tabular}{|c|c|c|c|c|c|}
\hline $\begin{array}{l}\text { Cropping } \\
\text { pattern }\end{array}$ & Years & $\begin{array}{l}\text { Gross return } \\
\left(\mathrm{Tk} . \mathrm{ha}^{-1}\right)\end{array}$ & $\begin{array}{c}\text { Total Cost of } \\
\text { cultivation (Tk. ha-1) }\end{array}$ & $\begin{array}{l}\text { Gross margin } \\
\left(\mathrm{Tk} . \mathrm{ha}^{-1}\right)\end{array}$ & $\begin{array}{l}\text { Benefit } \\
\text { cost ratio }\end{array}$ \\
\hline \multirow[t]{3}{*}{$\mathrm{ICP}$} & $2014-15$ & 274800 & 160850 & 113950 & 1.70 \\
\hline & $2015-16$ & 276600 & 160850 & 106750 & 1.66 \\
\hline & Mean & 271200 & 160850 & 110350 & 1.68 \\
\hline \multirow[t]{3}{*}{ ECP } & $2014-15$ & 214500 & 137550 & 76950 & 1.55 \\
\hline & 2015-16 & 209700 & 137550 & 72150 & 1.52 \\
\hline & Mean & 212100 & 137550 & 74550 & 1.54 \\
\hline
\end{tabular}

\section{Conclusion}

Two years study revealed that four crops based cropping pattern such as Boro (var. BRRI dhan28)-T. Aus (var. BRRI dhan48)- T. Aman (var. Binadhan-11)-Mustard (var. BARI Sarisha14) is agronomically feasible and economically profitable compared to the existing farmers cropping pattern Boro (var. BRRI dhan28)-T. Aus (var. BRRI dhan48)-T. Aman (var. BRRI dhan49)-Fallow. So, the farmers of Cumilla region could be suggested to grow mustard under four crops based cropping pattern for getting maximum profit.

\section{References}

BBS. 2019. Statistical Yearbook of Bangladesh. Bangladesh Bureau of Statistics, Ministry of Planning. Dhaka. Bangladesh.

Bhowal, S.K., M.M. Bashir and M.H. Hossain. 2019. Development of Vegetable based Cropping Pattern in Cumilla Region. Bangladesh Agron. J. 22(1): 7-13.

Azad, A.K., M. Miaruddin, M.A. Wahab, M.H.R. Seikh, B.L. Nug and M.H.H. Rahman. 2020. Krishi Projukti Hatboi (Handbook on Agro-Technology), 9th edition, Gazipur-1701, Bangladesh.

DAE. 2019. Paper presented at annual research-extension regional review and program planning workshop. Khamarbari, Cumilla, Bangladesh.

Mondal, R.I., F. Begum, A. Aziz and S.H. Sharif. 2015. Crop sequences for increasing cropping intensity and productivity. SAARC J. Agri. 13(1):135-147.

Mondal, R.I., F. Begum and A. Aziz. 2014. Four crop based cropping pattern in one piece of land in a year (T. Aman-Mustard-Boro-T. Aus). (Bengali Booklet) Bangladesh Agricultural Research Institute, Gazipur-170, Bangladesh. 31p.

Nazrul, M.I., M.R. Shaheb, M.A.H. Khan and A.S.M.M.R. Khan. 2013. On-Farm evaluation of production potential and economic returns of potato-rice based improved cropping system. Bangladesh Agron. J. 16(2): 41-50.

Nazrul, M.I., M.K. Hasan and M.R.I. Mondal. 2017. Production potential and economics of mungbean in rice based cropping pattern in Sylhet region under AEZ 20. Bangladesh J. Agril. Res. 42(3): 413-424.

Naher, Q., M.R. Amin, M.R. Islam, M.A. Ali, A.K. Choudhury, M.K. Hasan and A.S.M.M.R. Khan. 2016. Location specific climate resilient agricultural technologies in Bangladesh. OFRD (OnFarm Research Division), BARI, Bangladesh. pp.37-38. 
Hossain, M.H., M.M. Bashir, S.K. Bhowal, Q. Naher, T. Zahan, M.K. Hasan and A.S.M.M.R. Khan. 2017. Production technology of four crop based cropping pattern Mustard-Boro-T. Aus-T. Aman in Cumilla region (Bengali Booklet). On-Farm Research Division, BARI, Bangladesh. p.23.

Hossain, I., R.I. Mondal, M.J. Islam, A. Aziz, A.S.M.M.R. Khan and F. Begum. 2014. Four crop based cropping pattern studies for increasing cropping intensity and productivity in Rajshahi region of Bangladesh. Bangladesh Agron. J. 17(2):55-60.

Krishna, A. and Reddy, K. 1997. Production potential and economics of different rice (Oryza sativa) based cropping systems in Andhra Pradesh. Indian J. Agril. Sci. 67(12):551-553.

Khan, M.A.H., M.A. Quayyum, M.I. Nazrul, N. Sultana and M.R.A. Mollah. 2005. On-Farm evaluation of production potential and economics of mustard-rice based improved cropping system. Bangladesh J. Socio. Res. Dev. 2(1): 37-42.

Khan, M.A.H., N. Sultana, N. Akter, M.S. Zaman and A.K. Choudhury. 2018. Increasing cropping intensity and productivity through mungbean inclusion in Wheat-Fallow-T. Aman rice cropping pattern. Bangladesh J. Agril. Res. 43(2): 333-343.

Khan, M.A.H., N. Sultana, N. Akter, S. Akhter and M.R. Ali. 2020. On-farm evaluation and system productivity of Garden pea-Boro-T. Aman rice cropping pattern in Mymensingh, Bangladesh Agron. J. 23(1): 37-46.

Ram, A.J., R.A. Dungrani, M.K. Arvadia and K.L. Sahrawat. 2012. Diversification of rice (Oryza sativa L.) based cropping systems for higher productivity, resource-use efficiency and economic returns in South Gujarat of India. Arch. Agron. Soil Sci.58(6): 561-572.

Saha, A., M. Nasim, M.H. Rashid and S.M. Sahidullah. 2017. Crop diversity and cropping patterns of Cumilla region. Bangladesh Rice J.21(2): 91-105.

Tomer, S.S. and A.S. Tiwari. 1990. Production potential and economics of different crop sequences. Indian J. Agron. 35(1\&2):30-35.

Verma, S.P. and S.C. Modgal. 1983. Production potential and economics of fertilizer application as resources constraints in maize, wheat crop sequence. Himachal J. Agric. Res. 9(2):89-92. 